ORIGINAL ARTICLE, MEDICINE

\title{
Lack of ERG-antibody in Benign Mimickers of Prostate Cancer
}

\author{
Svitlana Y. Bachurska ${ }^{1,2}$, Dmitriy G. Staykov ${ }^{1,2}$, Georgi P. Ivanov ${ }^{1,2}$, Veselin T. Belovezhdov ${ }^{1,2}$ \\ ${ }^{1}$ Department of General and Clinical Pathology, Faculty of Medicine, Medical University of Plovdiv, Plovdiv, Bulgaria \\ 2 St. George University Hospital, Plovdiv, Bulgaria
}

Correspondence: Svitlana Bachurska, Department of General and Clinical Pathology, Faculty of Medicine, Medical University of Plovdiv, Plovdiv, 15A Vassil Aprilov Blvd., 4002 Plovdiv, Bulgaria E-mail: svitba@gmailcom Tel.: +359886336133

Received: 24 July 2015

Accepted: 04 April 2016

Published: 30 April 2016

Key words: prostate cancer, mimickers, adenosis, partial atrophy, simple atrophy, ERG, core needle biopsy

Citation: Bachurska SY, Staykov DG, Ivanov GP, Belovezhdov VT. Lack of ERG-antibody in benign mimickers of prostate cancer.

Folia Medica 2016;58(1);48-53, doi: 10.1515/folmed-2016-0007
Introduction: Prostate carcinoma (PC) is the second most diagnosed cancer in men worldwide. Prostate tissue in needle biopsy expresses a wide variety of architectural patterns some of which are difficult to interpret. Immunohistochemical markers, such as AMACR, p63 and 34ßE12 that are currently used in diagnosing prostate cancer, are of great value, but often their interpretation is ambiguous. In 2005 Tomlins et al. identified an emerging marker, erythroblastosis E26 rearrangement gene (ERG), which is a member of the family of genes encoding erythroblasttransformation specific transcription factors (ETS) with frequent expression in PC.

Aim: The aim of this study was to investigate the expression of ERG in benign mimickers of PC in needle biopsies and its diagnostic value alone and in combination with AMACK and $34 \beta E 12$.

Results: Of the selected 46 biopsies, two were eventually diagnosed as PC Gleason score 6 as they were simultaneously ERG and AMACR-positive and 34ßE12negative. One case was considered atypical. The remaining 43 biopsies were diagnosed as benign cases: simple atrophy in 13 cases, partial atrophy in 11, adenosis in 9 , basal cell hyperplasia in 3, post-atrophic hyperplasia in 3, clear cell hyperplasia in 2 and sclerotic adenosis in 2 cases. None of the 43 benign cores showed evidence of ERG expression.

Conclusion: ERG could be preferably used in diagnosing prostate needle biopsies, lesions that are hard to interpret and controversial expression of AMACR/34ßE12.

\section{INTRODUCTION}

Prostate carcinoma (PC) is the second most diagnosed cancer in men worldwide and among leading causes of cancer-related death. It has been estimated that by 2030 there will be nearly 1.7 million new cases and half a million deaths from prostate cancer. ${ }^{1}$ The core needle biopsy remains a crucial method for PC diagnosis. Prostate tissue expresses a wide variety of the architectural patterns some of which are difficult for interpretation. Many normal anatomical structures as seminal vessels and paraganglia, reactive and pathophysiological conditions as adenosis, atrophy, hyperplasia and metaplasia could mimic architectural and cytological features of PC. ${ }^{2}$ These conditions require no additional treatment so recognising them correctly is of paramount importance. Immunohistochemical (IHC) markers (AMACR, p63 and $34 \beta E 12$ ) currently recruited in PC diagnosis are of great value, but often their interpretation is controversial. Previous studies reported about 20\% of cases containing adenosis, partial atrophy and post-atrophic hyperplasia that had positive AMACR expression and complete lack of expression of basal layer markers. ${ }^{3,4}$ In 2005 Tomlins et al. identified an emerging marker, erythroblastosis E26 rearrangement gene (ERG), which is a member of the family of genes encoding erythroblast-transformation specific transcription factors (ETS) with frequent expression in PC. A pathway of the ERG overexpression is recurrent chromosomal rearrangements after gene fusion including ERG and androgen - presenting gene TMPRSS2 (Transmembrane Protease Serine 2 gene). ${ }^{5}$ ERG expression has been found in $50 \%$ of PC cases, but little is known about the presence and absence of this gene alteration in such prostatic lesion as adenosis, atrophy and hyperplasia., ${ }^{6,7}$

\section{AIM}

The aim of this study was to investigate the expression of ERG in benign mimickers of PC in needle biopsies and find its diagnostic value separately and in combination with AMACK and 34ßE12. 


\section{MATERIALS AND METHODS}

Out of 1710 consecutive prostate needle biopsies diagnosed between January 2008 and December 2012 in our medical institution 46 cases were initially diagnosed as benign exhibiting architectural patterns for adenosis, atrophy and hyperplasia based on HE staining.

IMMUNOHISTOCHEMICAL EVALUATION OF ERG, AMACR AND $34 \beta E 12$

Formalin-fixed paraffin-embedded prostate biopsy tissue samples were cut in $4-\mu \mathrm{m}$-thick sections. IHC was performed manually using monoclonal antibodies against ERG, AMACR and 34ßE12. Antigen retrieval was performed in EDTA buffer ( $\mathrm{pH}$ 6.0) for $40 \mathrm{~min}$ at $95^{\circ} \mathrm{C}$ and then $10 \mathrm{~min}$ at room temperature. The slides were incubated with primary antibodies as follows: anti-ERG (1:200 dilution, clone ERP 3864, rabbit monoclonal antibody, Abcam), AMACR (ready for use, BSB 5395, mouse monoclonal antibody, BioSB) and 34ßE12 (ready for use, BSB 5059, mouse monoclonal antibody, BioSB) for $90 \mathrm{~min}$ at room temperature. The IHC reaction was visualized with a peroxidase-based brown detection (Mouse/ Rabbit PolyDetector HRP/DAB System, BioSB). The slides were counterstained with hematoxylin. Simultaneously positive and negative IHC controls for the AMACR and 34ßE12 were performed.

Only sections with positive endothelial ERG staining as an internal control were included. ERG expression was evaluated in suspected zones and considered positive if any nuclear staining was observed to vary from weak to strong. All cases were evaluated separately by 3 pathologists and the final diagnosis was rendered as benign, atypical or PC based on morphology and the results of IHC study.

\section{Statistical ANALYsis}

All data were analyzed by descriptive and nonparametric analysis. Statistical analysis of antibodies sensitivity and specificity was performed by ROCcurve analysis. Statistical significance was accepted at $\mathrm{p}<0.05$. SPSS 19.0 was used in the analysis.

\section{RESULTS}

The mean age of the 46 men with initial diagnosis of benign prostatic tissue was 70 yrs (range, 52 to $83 \mathrm{yrs}$ ) and their mean pre-biopsy serum prostatespecific antigen level was $14.5 \mathrm{ng} / \mathrm{mL}$ (range 2.7 to $40 \mathrm{ng} / \mathrm{mL}$ ). Of the selected 46 biopsies, 2 (4.34\%) cores showed positive and $44(95.66 \%)$ negative ERG expression in the suspected areas. AMACR demonstrated positive cytoplasmic staining in 19 $(41.30 \%)$ of the same foci and completely absent in the remaining $27(58.70 \%) .41(89.13 \%)$ of the biopsies demonstrated positive $34 \beta E 12$ expression in basal cells and only 5 cases $(10.87 \%)$ showed lack of staining.

The only 2 ERG-positive cores were simultaneously AMACR-positive and 34ßE12-negative so they were finally diagnosed as PC Gleason scored 6. One case was considered "atypical" due to positive expression of the two markers AMACR and $34 \beta E 12$, but negative ERG staining and sufficient architectural and cellular criteria for PC.

The remaining 43 biopsies were diagnosed as benign exhibiting simple atrophy in 13, partial atrophy in 11, adenosis in 9, basal cell hyperplasia in 3, post-atrophic hyperplasia in 3 , clear cell hyperplasia in 2 and sclerotic adenosis in 2 cases (Fig. 1). Among them AMACR demonstrated complete absence of expression in $27(62.79 \%)$ and positive in $16(37.21 \%)$ of the biopsies. Weak to

Table 1. Immunohistochemical characteristic of the expression of ERG, AMACR and 34ßE12 in different entities of benign mimickers

\begin{tabular}{|c|c|c|c|c|c|c|c|c|c|c|c|}
\hline \multirow{2}{*}{ Lesion } & \multirow{2}{*}{$\begin{array}{c}\text { Total } \\
\mathbf{n}\end{array}$} & \multicolumn{2}{|c|}{ ERG- } & \multicolumn{2}{|c|}{ AMACR+ } & \multicolumn{2}{|c|}{ AMACR - } & \multicolumn{2}{|c|}{ 34ßE12+ } & \multicolumn{2}{|c|}{ 34ßE12 - } \\
\hline & & $\mathbf{n}$ & $\%$ & n & $\%$ & n & $\%$ & n & $\%$ & $\mathbf{n}$ & $\%$ \\
\hline Simple atrophy & 13 & 13 & 100.00 & 6 & 46.15 & 7 & 53.85 & 12 & 92.30 & 1 & 7.70 \\
\hline Partial atrophy & 11 & 11 & 100.00 & 3 & 27.27 & 8 & 72.73 & 10 & 90.90 & 1 & 9.10 \\
\hline Adenosis & 9 & 9 & 100.00 & 4 & 44.44 & 5 & 55.56 & 8 & 88.88 & 1 & 11.12 \\
\hline Basal cell hyperplasia & 3 & 3 & 100.00 & 1 & 33.33 & 2 & 66.67 & 3 & 100.00 & 0 & 0.00 \\
\hline Post-atrophic hyperplasia & 3 & 3 & 100.00 & 0 & 0.00 & 3 & 100.00 & 3 & 100.00 & 0 & 0.00 \\
\hline Clear cell hyperplasia & 2 & 2 & 100.00 & 1 & 50.00 & 1 & 50.00 & 2 & 100.00 & 0 & 0.00 \\
\hline Sclerotic adenosis & 2 & 2 & 100.00 & 1 & 50.00 & 1 & 50.00 & 2 & 100.00 & 0 & 0.00 \\
\hline
\end{tabular}


moderate cytoplasmic staining were observed almost in all morphological groups except post-atrophic hyperplasia. Positive expression of $34 \beta \mathrm{E} 12$ were identified in $40(90.00 \%)$ and negative in $3(10.00 \%)$ cases. The 34ßE12-negative group contained only atrophic lesions. None of the 43 benign cores showed evidence of ERG expression (Table 1).

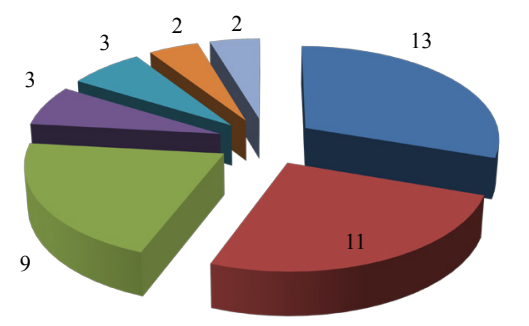

- Simple atrophy - Partial atrophy adenosis - Basal cell hyperplasia - Postatrophoc hyperplasia - Clear cell hyperplasia $\square$ Sclerotic adenosis

Figure 1. Distribution of benign mimickers of prostate cancer (n).

\section{DISCUSSION}

This is the first study investigating ERG expression in benign prostatic tissue of a population of Bulgarian men. We evaluated 46 prostate needle biopsies exhibiting histological patterns of benign mimicker of PC. Of 46 cases, after final consensus 43 were diagnosed as benign and none of the 43 showed evidence of ERG expression. Our results are consistent with previous studies reporting ERG staining as highly specific for PC and its exceedingly rare appearance in the benign glands. Tomlins et al. identified ERG expression in only 2 of 162 cores $(1 \%)$ diagnosed as benign. ${ }^{8}$ In the series of 65 benign biopsies $\mathrm{He}$ et al. found nuclear ERG staining in 1 morphologically benign gland. ${ }^{9}$ Van Leenders et al. detected weak ERG expression in 5 benign glands in a set of 87 needle biopsies. ${ }^{10}$ The researchers reported that ERG-positive benign glands were located adjusted to or in between the neoplastic glands. They also suggested that there is a possibility of undersampled ERG-positive cancer presented in close proximity to the ERG-positive benign glands.

The present study found that $2.69 \%$ of the biopsies demonstrated cellular and architectural patterns of PC which are not sufficient for definitive diagnosis. Previous studies reported partial atrophy, simple atrophy and adenosis as the most frequent benign lesions that caused difficulty for pathologists. ${ }^{3,11}$ In our series the majority of benign mimickers were also presented by partial and simple atrophy $(55.81 \%)$, followed by adenosis $(25.58 \%)$ and different hyperplastic changes $(18.60 \%)$. The additional factor that contributes to the difficulty in distinguishing these lesions from PC is that they may show positive AMACR staining as well as lack of $34 \beta E 12$ expression in basal cells. In the current study the routine IHC cocktail was able to resolve $29(63.04 \%)$ of the cases. Herein, 13 out of $16(81.25 \%)$ of the benign cases that demonstrated weak to strong cytoplasmic AMACR staining were diagnosed as adenosis, simple and partial atrophy. In contrast, 34ßE12 expression was more homogenous and only 3 benign cases showed lack of $34 \beta E 12$ in basal cells. Interestingly, there were again cores presenting adenosis, simple and partial atrophy. Our results are not surprising since worldwide recognized uropathology practice reported $79 \%$ and $67 \%$ of AMACR positive cases in atrophy and adenosis respectively. ${ }^{3}$ Previously published data confirmed by our results demonstrated that biopsies containing benign mimickers of PC are difficult for interpretation even with the assistance of routine IHC markers.

Therefore, scientists initiated investigations of the diagnostic utility of ERG-antibody in workup of challenging biopsies containing small foci of high-grade PC, benign mimickers and "atypical glands suspicious for cancer". Shah et al. found that positive ERG expression contributed to the correct diagnosis in $28 \%$ of the cases. Moreover, they noted positive AMACR expression in $40 \%$ of noncancerous cases and negative ERG staining in all of them. ${ }^{12}$ Cheng et al. investigated only needle biopsies presenting foci of adenosis and found no evidence of ERG expression in 55 out of 55 cases. ${ }^{13}$ Undoubtedly, a tumor marker, which demonstrates better specificity for PC and is not expressed in benign glands, may add the diagnostic value of AMACR/34ßE12 IHC cocktail for better identification of "atypical" lesions, including benign mimickers of PC. In this study, the utility of ERG has contributed in cases where both markers (AMACR/34ßE12) showed positive expression in suspected glands (Fig. 2). Positive staining of $34 \beta E 12$ in the basal cells complemented by negative ERG expression proved the benign character of the lesion. Statistically, a combination ERG/34ßE12 (AUC 0,981, SE 0,00873) showed a higher specificity and sensitivity than the combination AMACR/34ßE12 (AUC 0.950, SE 0.0174, $\mathrm{p}=0.017$ ) (Fig. 3). 


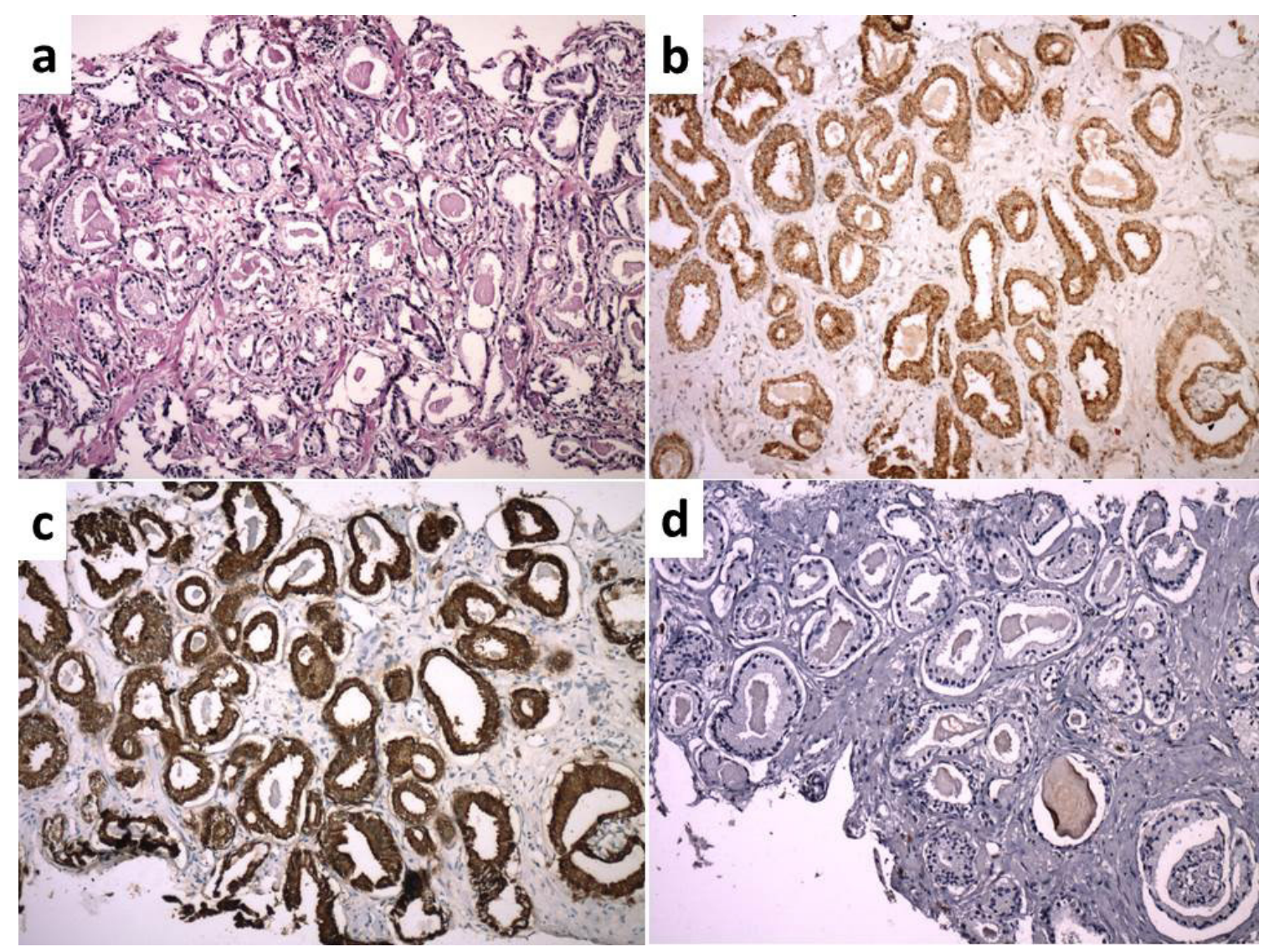

Figure 2. a) Prostate core presenting crowded glands with mild cellular atypia and diagnosed as adenosis (HE, $\mathrm{x} 100)$, b) Strong cytoplasmic AMACR staining in the luminal cells (x100), c) Strong expression of $34 \beta E 12$ in basal cells of suspicious acini (x100), d) Lack of nuclear staining of ERG in the area of crowded glands and positive nuclear ERG expression in endothelial cells of the vessels as an internal control (x100).

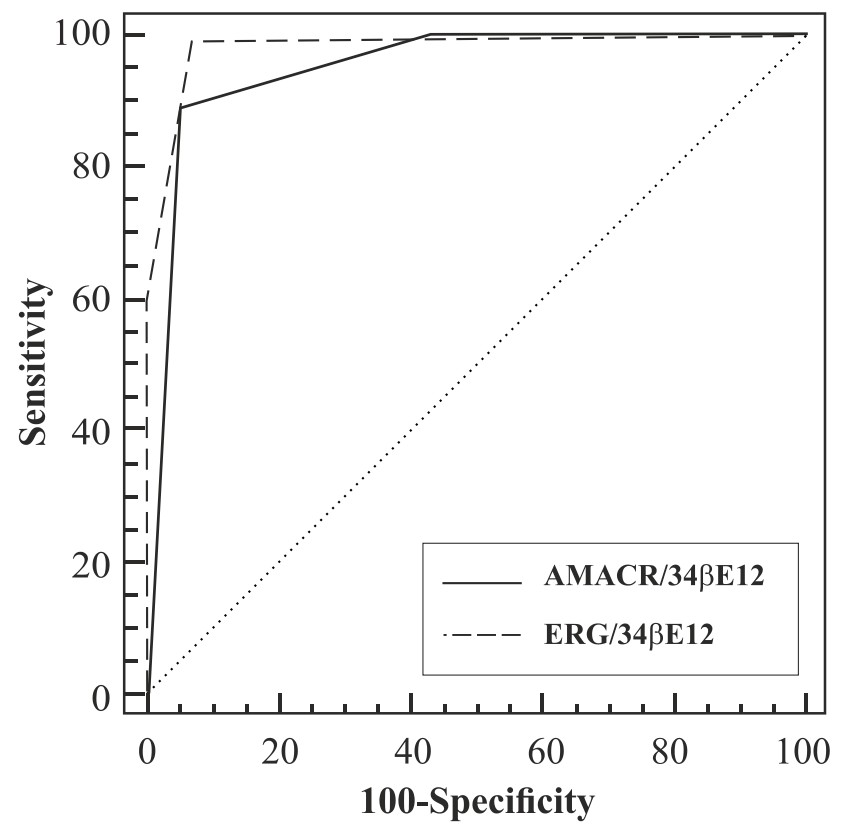

Figure 3. ROC-curves of $A M A C R / 34 \beta E 12$ and ERG/34ßE12 IHC combination illustrated better specificity and sensitivity of the latter.
In summary, this is the first study that investigated ERG expression in benign prostatic tissue in a Bulgarian population and all 43 biopsies diagnosed as benign showed no evidence of ERG expression. Although routine IHC cocktail was able to resolve $29(63.04 \%)$ of the cases, ERG expression assisted in cores where both markers (AMACR/343E12) were positive in suspected glands. We conclude that ERG could be preferably used in diagnosing prostate needle biopsies, lesions that are hard to interpret and controversial expression of AMACR/34ßE12.

\section{ACKNOWLEDGEMENTS}

This work was supported by the Medical University, Plovdiv (Grant HO-11/12). The funding party had no participation in the study design, data collection, analysis and preparation of manuscript.

\section{CONFLICT OF INTEREST}

The authors declare that there is no conflict of interest. 


\section{REFERENCES}

1. Ferlay J, Shin HR, Bray E, Forman D, Mathers C, Parkin DM. GLOBOCAN 2008, Cancer incidence and mortality worldwide: IARC CancerBase No. 10. Lyon, France: International Agency for Research on Cancer; 2010. Available from: http://globocan.iarc. fr/Pages/fact_sheets_cancer.aspx.

2. Karaivanov M, Ivanova V. Histological differential diagnosis of prostate carcinoma. Review part I: acinar proliferations that mimic prostate adenocarcinoma. Bulgarian Medicine 2003;11(5):11-5.

3. Herawi M, Parwani AV, Irie J, Epstein JI. Small glandular proliferations on needle biopsies: most common benign mimickers of prostatic adenocarcinoma sent in for expert second opinion. Am J Surg Pathol 2005;29:874-80.

4. Brimo F, Epstein JI. Immunohistochemical pitfalls in prostate pathology. Human Pathology 2012;43:313-24

5. Tomlins SA, Rhodes DR, Perner S, et al. Recurrent fusion of TMPRSS2 and ETS transcription factor genes in prostate cancer. Science 2005;310:644-648.

6. Mosquera JM, Mehra R, Regan MM, et al. Prevalence of TMPRSS2:ERG fusion prostate cancer among men undergoing prostate biopsy in the United States. Clin Cancer Res 2009;15:4706-11.

7. Tomlins SA, Bjartell A, Chinnaiyan AM, Jenster G, Nam RK, Rubin MA, Schalken JA. ETS gene fusions in prostate cancer: from discovery to daily clinical practice. Eur Urol 2009;56:275-86.
8. Tomlins SA, Palanisamy N, Siddiqui J, Chinnaiyan AM, Kunju LP. Antibody-based detection of ERG rearrangements in prostate core biopsies, including challenging cases. Arch Pathol Lab Med 2012;136:935-46.

9. He H, Magi-Galluzzi C, Li J, Carver P, Falzarano S, Smith K, Rubin MA, Zhou M. The diagnostic utility of novel immunohistochemical marker ERG in the workup of prostate biopsies with "atypical glands suspicious for cancer”. Am J Surg Pathol 2011;35(4):608-14.

10. Van Leenders, Boormans JL, Vissers CJ, Hoogland AM, Bressers AA, Furusato B, Trapman J. Antibody EPR3864 is specific for ERG genomic fusions in prostate cancer: implications for pathological practice. Mod Pathol 2011;24(8):1128-38.

11. Chan TY, Epstein JI. Follow-up of atypical prostate needle biopsies suspicious for cancer. Urol 1999;53(2):351-5.

12. Shah RB, Tadros Y, Brummell B, Zhou M. The diagnostic use of ERG in resolving an "atypical glands suspicious for cancer" diagnosis in prostate biopsies beyond that provided by basal cell and $\alpha$-methylacyl-CoA-racemase markers. Hum Pathol 2013;44(5):786-94.

13. Cheng L, Davidson DD, MacLennan GT, et al. Atypical adenomatous hyperplasia of prostate lacks TMPRSS2-ERG gene fusion. Am J Surg Pathol 2013;37(10):1550-4. 


\title{
Отсутствие экспрессии ERG-антитела в доброкачественных процессах, имитирующих рак простаты
}

\author{
Свитлана Ю. Бачурская, Дмитрий Г. Стайков, Георгий П. Иванов, Веселин Т. Беловеждов \\ Кафедра общей и клинической патологии, Университетская больница "Св. Георгий", Медицинский университет, Пловдив, \\ Болгария
}

Введение: Рак предстательной железы (РПЖ) является вторым наиболее часто диагностированым раком у мужчин в мировом масштабе. Ткани простаты В пункционной биопсии демонстрируют широкий спектр архитектурных моделей, некоторые из которых трудно поддаются интерпретации. Иммуногистохимические маркеры, такие как AMACR, p63 и $34 \beta E 12$, которые в настоящее время часто используются в диагностике рака предстательной железы, имеют большое значение, но часто их интерпретация неоднозначна. В 2005 Tomlins и коллектив идентифицировали новый маркер, erythroblastosis E26 rearrangement gene (ERG), который является членом семейства генов, кодирующих erythroblasttransformation specific transcription factors (ETS) с частой экспрессией в РПЖ.

Целью данного исследования является изучение экспрессии ERG в доброкачественных процессах, имитирующих рак простаты, в пункционных биоп- сиях как самостоятельно, так и в комбинации с АМАСК и $34 \beta$ E12.

Результаты: Из отобранных 46 биопсий, две были диагностированы как РПЖ (Глисон 6), так как они были одновременно ERG и AMACR-положительными и 34ßE12-отрицательными. Один случай был рассмотрен как атипичный. Оставшиеся 43 биопсии были диагностированы как доброкачественные: простая атрофия в 13, частичная атрофия в 11, аденоз в 9, базальная гиперплазия в 3, постатрофическая гиперплазия в 3, светлоклеточная гиперплазия в 2 и склеротический аденоз в 2-х случаях. Ни один из 43 доброкачественных процессов не показал наличной экспрессии ERG.

Вывод: ERG может стать предпочитаемым маркером при диагностике пункционных биопсий предстательной железы, содержащих процессы, которые трудно интерпретировать и которые демонстрируют противоречивую экспрессию AMACR и $34 \beta E 12$.

Ключевые слова: рак предстательной железы, аденоз, частичная атрофия, простая атрофия, ERG, пункционная биопсия 